\title{
Insect Pest Complex of Tomato Crop and its Population Dynamics and Correlation with Weather Factors
}

\author{
Nistha Rawat* \\ Department Of Entomology, College Of Agriculture, G. B. Pant, University of Agriculture \\ And Technology, Pantnagar, U. S. Nagar (263145), Uttrakhand, India \\ *Corresponding author
}

\section{A B S T R A C T}

\section{Keywords}

Insect pest complex, Tomato crop, Population

dynamics, Weather factors

Article Info

Accepted:

24x July 2020

Available Online:

10 August 2020
Tomato has become one of the most important and remunerative vegetable crop grown in tropical and subtropical regions of the world for fresh market and processing, constituting an important part of our human diet. Like other vegetables, tomato is more prone to insect pests and diseases mainly due to their tenderness and softness compared to other crops. Among other various factors responsible for low yield of tomato, insect pests are highly destructive causing serious damage and are responsible for lowering the yield of tomato crop. It is an important aspects to recognize the pest complex of tomato crop and to identify how they are correlated with weather factors. So that we could make focasting models of pests related to weather conditions and make proper effort for management of these insect pests.

\section{Introduction}

India is the second largest producer of vegetables in the world after China. Vegetables act as a rich source of vitamins and minerals, in which other food materials are deficient. Tomato (Lycopersicon esculentum Mill.) of the family Solanaceae is one of the most important vegetables grown in the world. It is a good source of vitamins. Tomato is a rich source of vitamin $\mathrm{A}$ and $\mathrm{C}$ and also known as 'poor man' orange. It is also reported to possess anti cancerous properties. It serves as an antioxidant as the $\beta$ carotene functions to help prevent and neutralize free radical chain reaction and ascorbic acid is an effective scavenger of super oxide, hydrogen peroxide and other free radicals. Per $100 \mathrm{~g}$ ripe tomato fruits contains Vitamin C (31.0 mg), Vitamin A (320 IU) and Riboflavin (0.001 mg), Nicotinic acid (0.4 $\mathrm{mg}$ ) and minerals viz., Potassium (114.0 mg), Sulphur (24.0 mg), Chlorine (38.0), Sodium (45.8 mg), Calcium (20.0 mg), phosphorus 
(36.0 $\mathrm{mg})$, Iron $(1.8 \mathrm{mg})$, Magnesium (15.0 mg), Copper (0.19 mg) (Aykroyd, 1963).

Like other vegetables, tomato is more prone to insect pests and diseases mainly due to their tenderness and softness compared to other crops (Sajjad et al., 2011).

Among other various factors responsible for low yield of tomato, insect pests viz., the fruit borer, Helicoverpa armigera (Hubner) and sucking insect pests viz. whitefly Bemesia tabaci (Genn)., Jassids, Amrasca biguttulla biguttula (Ishida), thrips Thrips tabaci (Lind) and serpentine leaf miner, Liriomyza trifolii (Burgess) are highly destructive causing serious damage and are responsible for lowering the yield of tomato crop. (Lal et al., 2008).Tomato crops can be infected with a large number of insects. However, only a few insect pests cause economic losses to this crop. Also by help of their population dynamics and their correlation with weather we could make forecasting modal for them, so that management action could be taken on time.

\section{Insect pest complex of tomato crop}

The tomato ecosystem can be characterized by having a few major key pests and many minor or secondary pests. Lange and Bronson (1981) made an extensive survey and recorded nearly 100 to 200 species ravaging tomato field. The most commonly occurring pests on tomato were: fruit borer Helicoverpa armigera(Hubner), common army worm, Spodoptera litura (Fabricius), beet army worm, Spodoptera exigua (Hubner), white fly, Bemisia tabaci (Gennadius), leaf miner, Liriomyza trifolii (Burgess) and two spotted mite Tetranychus urticae (Koch). Of these, fruit borer, white fly, leaf miner were found to be most hazardous that caused substantial yield loss in tropical and subtropical tomato producing regions of the India (Binyanson
1997). The presence of fruit borer Helicoverpa armigera (Hubner), Hardwick, army worm (Spodoptera exigua Hubner), whitefly (Bemisia tabaci Gennadius), leaf miner (Liriomyza trifolii Burgess) and spider mites (Tetranychus cinnabarinus Boisdual) as the major insect pest attacking tomato crop also reported in karnataka. (Nagaraju et al., 2002). Even Foster (2010) reported eleven insect pest on tomato crop viz, fruitworms Helicoverpa zea (Boddie); Manduca quinquemaculata (Haworth); Manduca sexta (L.) (Tobacco hornworms); Spodoptera ornithogalli (Guence) (yellow-striped armyworm); Leptinotarsa decemlineata (Say) (Colorado potato beetle); Peridroma saucia (Hubner) (variegated cutworm), Agrotis ipsilon (Hufnagel) (Black cutworm), Myzus persicae (Sulzer) (Green peach aphid), Tetranychus urticae, Koch (two spotted spider mites) and Empoasca fabae (Harris) (Potato leafhopper) attacking tomato crop from United States. Kumar (2008) recorded five species of insect pests viz., whitefly (Bemisia tabaci), aphid (Aphis gossypi), jassid (Amrasca devastance), serpentine leaf miner (Liriomyza trifolii) and fruit borer (Helicoverpa armigera) belonging to 3 orders and 5 families. Singh et al., (2011) worked out the biodiversity of insect pests of tomato in eastern region of Uttar Pradesh and reported that the jassid, Amrasca bigutulla bigutulla (Ishida); aphids Aphis gossypi (Glover) and Myzus persicae (Sulzer); White fly Bemisia tabaci (Gennadius); cutworm, Agrotis sp.; tobacco caterpillar, Spodoptera litura (Fabr.) and tomato fruit borer Helicoverpa armigera (Hubner), as the key pest of tomato infesting tomato crop, hampering the growth of tomato plants.

The American serpentine leaf miner, Liriomyza trifolii (Burgess) has also reported as a major pest of tomato crop by Rai et al., (2013) in north-west region of Uttar Pradesh. Other major insect pests of tomato crop in this 
region as reported by them were tomato fruit borer (Helicoverpa armigera), aphids (Aphis gossypii, Myzus persicae), jassid (Amarasca biguttula) and root knot nematodes (Meloidogyne sp).

Ofori et al., (2014) reported total 14 species of insects, including harmful and beneficial insects from tomato ecosystem. The harmful insects as reported by them were: Aphis craccivora (Koch) (Hemiptera: Aphididae), Phenococcus sp, Nezara viridula (Linnaeus) (Heteroptera: Pentatomidae), Gryllus campestries (Linnaeus) (Orthoptera: Acrididae), Psylla mali, Zonocerus variegatus, Dysdercus sp, Omocestus viridulus, (Linnaeus) (Orthoptera), Bemisia tabaci (Gennadius) (Hemiptera, Aleyrodidae) etc and considered as major problems to tomato production

Among the various pest of tomato crop, Helicoverpa armigera considered as the most serious pest causing 50-60\% damage (Singh and Singh, 1975). Among various pests of tomato, $H$. armigera has been reported to be the most destructive insect pest and causes considerable loss in quantity as well as quality of the tomato fruits (Tewari and Krishnamoorthy, 1984). Roghupathy et al., (1989) also reported that out of more than seventeen insect pests of tomato in major tomato growing area of India, Helicoverpa armigera to be the most dominant pest. Chibber and Singh (2003) reported tomato fruit borer (Helicoverpa armigera) and whitefly (Bemesia tabacci) as the major pests of tomato crop in a survey conducted in Bhawar area of Uttrakhand. Whitefly not only sucks the sap of the plant but also spread many viral disease by actting as vector. Leaf hopper is also a major sucking pest of economically important crops such as cotton, tomato and cowpea has been reported by Jotwani et al., (1966) from Solan, Himanchal pradesh. Alam et al., (2007) reported
Helicoverpa armigera as a key pest of tomato in Jessore, Bangladesh with infestation range upto 46.85 per cent. Jandial and Kumar (2007) conducted field surveys in western Uttar Pradesh and reported fruit borer (Helicoverpa armigera) as one of the most serious pest of tomato.

The whitefly Bemisia tabaci (Gennadius) (Homoptera: Aleyrodidae) is an important pest of tomato plant (Butter et al., 1978) infesting wide range of crops, including tomato. The wide range of geographical distribution with variety of host range makes it difficult to control (Naresh et al., 1980). B. tabaci which sucks the phloem sap of growing tomato plant also transmits tomato yellow curl viruses (Rataul et al., 1989). Such direct feeding also induces plant physiological disorders, which results in early shedding of immature fruit-parts (Yokomi et al., 1990; Bharathan et al., 1990). Both adult and immature stages of this insect cause direct damage through sucking the plant sap (Brown et al., 1995) and causes insurmountable losses to tomato plants (Gerling, 1986).

A.biguttula biguttula and Liriomyza trifolii are the other two major and regular pests of tomato in Tarai region of Uttarakhand.

\section{Population dynamics of Helicoverpa armigera and correlation with weather factors}

Constant monitoring of all major pests under field condition is a must for timely prevention of sudden epidemic outbreaks and for devising and applying suitable pest management strategies., for this an important aspect is their correlation with weather factors viz., temperature, relative humidity, rainfall, wind speed etc. How these weather factors are responsible for abundance of insect pest population. An experiment reported that larval population of Helicoverpa armigera 
(Hubner) was positively affected by different magnitude of high rainfall whereas 80.00 per cent relative humidity was found conductive in population build up (Meng et al., 1962). Study conducted by Yadav et al., (1983) at Patancheru (Andhra Pradesh) reported that the peak period of larval population of the Helicoverpa armigera occurred in the month of April.

Parihar and Singh (1986) observed a significant increase in fruit infestation by Helicoverpa armigera Varanasi during April in comparison to the fruits picked up in the month of March. Considering the impact of abiotic factors on fruit infestation, the impact was in the same pattern as observed in the case of population build up i.e. temperature played positive relation, enhancing the relative humidity and rainfall had the negative association with the fruit infestation.In another study carried out by Sharma and Chaudhari (1988) found a positive impact of temperature on population buildup of Helicoverpa armigera on tomato crop. The findings of Devi et al., (1991) also revealed maximum temperature of $25.9-27.50 \mathrm{C}$ to be conductive in enhancing the population of Helicoverpa armigera.

Rajput (1991) reported the ovipositon period of Helicoverpa armigera from begning of March to end of May with peak population in the last week of March and which decrease during June to July. Lal and Lal (1966) also observed maximum tomato fruit borer infestation at the end of March. Incidence of Helicoverpa armigera was observed from March to May with peak population in the month of April. (Pandey et al., 1997)

Ravi and Verma (1997) on the other hand, studied the seasonal incidence of Helicoverpa armigera on chick-pea in Raichur, Karnataka. They recorded the first incidence of this pest in the first week of January with peak population in the middle of March. Mahapatra et al., (2007) also observed higher number of moths trapped during March-April on tomato crop.

Singh et al., (2011) studied the population dynamics of Helicoverpa armigera on tomato crop in eastern region of Uttar Pradesh. According to them the first appearance of larvae of this pest was marked in the month of December, followed by a gradual increase during vegetative growth of crop and peak population at fruiting stage, thereafter, a decline in larval population.

Kurl and Kumar (2010) found that the larvae of Helicoverpa armigera appeared on tomato crop in $2^{\text {nd }}$ standard week of January and continued till $21^{\text {st }}$ standard week. The highest population build-up of larvae was recorded in $15^{\text {th }}$ standard week. Thereafter, the larval population was declined. According to them average maximum temperature of $32.9^{\circ} \mathrm{C}$, minimum temperature of $17.9^{\circ} \mathrm{C}$, morning humidity $74.2 \%$, evening humidity of $30.1 \%$ coupled with rainfall of $6.0 \mathrm{~mm}$ prevailing during $10^{\text {th }}$ standard week to $15^{\text {th }}$ standard week were found most suitable for larval population build-up. Above and below of these ranges did not favour the development of larvae.

On the basis of data collected by Wakil et al., (2010) on the fluctuation in population of Helicoverpa armigera in Pakistan revealed maximum larval population (5.2 larvae/plant) with $32.6 \%$ fruit infestation on tomato during 2008 and 2009. However, the minimum larval population (1.4 larvae/plant) inflicted 14.75 fruit infestation. According to them the temperature was found to have a positive correlation while, relative humidity exhibited a negative interaction with the larval population and fruit infestation in tomato.

Ali and Aheer (2010) conducted an experiment on the influence of weather on the moth catches of Helicoverpa armigera at 
various cotton based agro-ecological sites viz., river, vegetable, orchards, clean cultivation and forest in Faisalabad and reported that sites did not show a significant difference regarding the moth catches, during the study period. However, vegetable-site showed maximum population of moth, per trap (0.54), followed by those of orchards (.29), forests (.19), river (.15) and clean cultivation (0.12). The minimum temperature exerted more contribution $(1.74 \%)$ percent role in population fluctuation of the Helicoverpa armigera followed by rainfall $(1.37 \%)$, relative humidity $(0.27 \%)$, maximum temperature $(0.23 \%)$ and average temperature (0.61\%). Jagginavar et al., (2007) stated that the minimum temperature had a significant positive correlation with moth population of Helicoverpa armigera.

Zafar et al., (2013) observed that larval population build up of Helicoverpa armigera build progressively from April 01 to April 12 and a tremendous decrease thereafter in sunflower. The result revealed that maximum temperature exhibited significant and positive correlation with the egg counts of Helicoverpa armigera. Whereas, relative humidity and rainfall had negative and significant correlation with the egs count.

Selvaraj and Bisht (2014) studied the incidence of Helicoverpa armigera Hub. on tomato (Solanum lycopersicum L.) at Pantnagar during the cropping season 201112 and 2012-13. They also noticed that the pest exhibited its incidence almost all through the tomato crop season. According to them the pest marked its first appearance in 7th and 9th standard meteorological week (SMW) i.e. (February and March), attain peak population in 16th and 15th SMW (April), respectively. The pest population exhibited non-significant correlation with various abiotic factors, but showed significant positive correlation with sunshine hours and significant negative correlation with evening relative humidity during.

Population dynamics of aphid (Aphis gossypii) and its correlation with weather factors

Seasonal activity and host range of Aphis gossypii in Punjab and recorded 37 species of host plants belonging to 16 families. The aphid exhausted its optimum population on okra and cotton during Sept.-Oct. and on brinjal (aubergine) and chilli during Oct.-Nov. It was found on tomato during February and was very active on melon and tomato in March while in April it attacked melon, chilli, okra, brinjal and tomato Kandoria et al., (1989). The population gradually declined from mid-May to the end of June on chilli, okra and cucurbits due to high temperature $\left(40^{\circ} \mathrm{C}\right)$. Kaushik Chakrborty (2011) studied the population dynamics of Aphis gossypii on tomato crop during four consecutive Kharif crop seasons at Alipurduar, West Bengal and reported that the population of this pest was initiated at about 48 standard meterological weeks (SMW), improved at first slowly upto 6 SMW attaining the maximum at about 8 SMW which was maintained upto about 11 SMW.

Population dynamics of leaf minor and its correlation with weather factors

Higher incidence of leaf miner on tomato during late March to early May at "Uttar Bhanga Krishi Vishwavidyalaya" Coochbehar. The population density of this pest slowly increased during early crop growing stages, but gained momentum from flowering stage onwards (Chaudhuri et al., 2004). The incidence of leaf miner on tomato appeared during first week of July $\left(27^{\text {th }}\right.$ standard week) with peak population during first week of October and January $\left(40^{\text {th }}\right.$ and $1^{\text {st }}$ standard week), but its outright 
absence during April and May (Hemalatha and Maheswari 2004). In another experiment, the peak incidence of $L$. trifolii (18.80 larvae per branch) was observed at 15 days after planting of tomato. From this stage onwards miner incidence gradually decreased to a minimum of 1.75 larvae per branch at 94 days old crop.

Saradhi and Patnaik (2004) conducted a survey in Bhubaneswar, Orissa and reported that L. trifolii infestation on tomato was maximum during the second and third weeks of February on tomato. Correlation studies revealed that diurnal temperature variation was negatively correlated $(r=-0.438)$ and the number of rainy days (distribution of winter rain) was positively correlated $(\mathrm{r}=-0.625)$ with the intensity of leaf infestation by the pest.

Reddy and Kumar (2005) studied the seasonal abundance of $L$. trifolii on tomato in a field experiment conducted in Karnataka, during kharif season. They observed the peak incidence of $L$. trifolii during March-April, which coincided with the vegetative and reproductive stages of the crop. They observed a significant decline in its population during November-December.

An extensive survey carried out by Ganapathy (2010) in Coimbatore, Tamil Nadu reported that the incidence of Leaf-miner on tomato was least in November $(9.0 \%)$ and maximum in March (32.5\%). During July and August on the other hand, incidence of damage was to the extent of 28.3 and 26.2 per cent respectively. He also observed that during the cold season the incidence of this pest was comparatively low (9.0 to $13.70 \%$ ).

Sharma et al., (2014) studied the fluctuations in population of Liriomyza trifolii (Burgess) and reported the first apperence of this pest in $14^{\text {th }}$ standard week $(1.10$ miners/plant $)$.
During $22^{\text {nd }}$ standard week the population attained its peak (7.80 miners/plant); followed by a steady decline in population. The leaf minor population was significantly correlated with maximum temperature positively but non-significantly with minimum temperature, relative humidity whereas maximum and minimum rainfall and sunshine hours were found to have negative correlation with leaf minor population.

\section{Population dynamics of whitefly and correlation with weather factors}

Singh and Tripathi (1991) found that the incidence of tomato leaf curl virus (TLCV) at low ebb when humidity was higher. It reached to the extent of 100 per cent during hot and dry season, due to incidence of white fly.

Effect of temperature and humidity on the population of whitefly was that during the summer crop the whitefly population was less at the initial stages of the crop, whereas during the winter crop the whitefly population was very high at the similar stages of the crop (Tripathi and Verma, 2002).

Sarangdevot et al., (2010) conducted an experiment and reported that the incidence of B. tabaci was first noticed in the 14th standard meteorological week and attained its peak during 22nd standard meteorological week. The whitefly population was positively correlated with mean temperature and negatively correlated with mean relative humidity. The positive correlation between the temperature and whitefly population can be attributed to the enhanced rate of development and reproduction of whitefly and found that the ovipositional activity of whitefly was maximum between $33^{\circ} \mathrm{C}$ to $37^{\circ}$ C temperatures.

The whitefly not only sucks the sap of tomato plant but also they are responsible for tomato 
leaf curl virus in tomato crop. They act as vector for this viral disease hence the ETL level for the vector is 1 .

Singh et al., (2011) carried out experiment in eastern region of Uttar pradesh and reported the incidence/occurrence of leaf curl (caused by tomato leaf curl virus (TLCV) transmitted by whitefly Bemisia tabaci (Gennadius) in 49th standard week when 5.33 and 3.67 per cent plants were found suffering from leaf curl in both the years of investigation i.e. 2005-06 and 2006-07, respectively. The spread of disease was gradually increased till 3rd week of January but it increased rapidly later and reached to the extent of 76.00 and 77.33 per cent leaf curl in 7 th standard week during 2005-06 and 2006-07, respectively. Thereafter, the incidence of disease was negligible during both the years of experimentation.

\section{References}

Alam, S. N., Rahman, A.K.M. Z. and Dutta, N.K. 2007. Annual report 20062007.Division of Entomology, BARI,Gazipur-1701. 163 pp.

Ali, A., Aheer, G. M., Ashfaq, M. and Akram, M. 2008. Influence of weather on moth catches of Helicoverpa armigera at various cotton based agroecological sites. Pak. Entomol., 30: 65-72.

Aykroyd, W. R. 1963. ICMR Special Report Series, No.42.

Binyanson, S.A. 1997. Comparison of three methods for establishing economic threshold levels for Jacobiasca lybica (de Berg) on eggplant. Ph.D. Thesis, University of Khartoum, Sudan

Chaudhuri, N. and Senapati, S.K. 2004.Incidence and biology of leaf miner, (Burg.) on tomato as influenced by weather conditions. Annals of Protection Sciences 12:55-58.

Chhibber, R.C. and Singh, C.P. 2003. Effect of Indoxacarb against Tomato Fruit Borer (Helicoverpa armigera Hub.) and Phytotoxicity to Tomato Plant. Advances in Plants and Agriculture Research.

Das, B.C., Patra1, S., Dhote, V.W., Alam, S.K.F., Chatterjee, M.L. and Samanta A. (2012) Mix formulations: An alternative option for management of gram pod borer Helicoverpa armigera and pod fly, Melanagromyza obtusa M. in pigeon pea Legume Research. 38 (3) 2015: 396-401

Devi, N., Raj, D. and Singh, M. 1991. Seasonal abundance of two noctuid pests (Plusia orichalcea (Fabr). and Heliothis armigera (Hubner) in North West Himalayas (India). J Entomol Res 15 (2), 120-124.

Foster,E.R. 2010. Management of insect pest on fresh market tomatoes; Purdue extension. E-97-W.

Ganapathy, N., Durairaj, C. and Aruppuchamy, K. 2010. Bio-ecology and management of serpentine leaf miner, Liriomyza trifolii (Burgess) in cowpea 23(1): 159-160.

Hemalatha, B. and Maheswari, T.U. 2004. Biology and seasonal incidence of serpentine leaf miner, Liriomyza trifolii (Burgess) ontomato in southern zone of Andhra Pradesh. Indian J. Ent., 66(2):107-110.

Jandial, V.K., Kumar. Anil. 2007. Seasonal incidence and population fluctuation of mustard aphid, Lipaphis erysimi Kalt. in relation to ecological parameters. Indian Journal of Entomology 69 (2): 162-67.

Kandoria, J.L., Jamwal, R. and S. Gurdip. 1989. Seasonal activity and host range of Aphis gossypii Glover in the Punjab. J. Insect Sci. 2:68-70

Kaushik Chakrborty.2011. Incidence of aphid Aphis gossypii Glover (Hemiptrea: aphidae) on tomato crop on agro clamitic condition of north part of west 
bengal, India.world journal of zoology 6(2):187-191.

Kumar, M. S., Bharath, M., Josmin, L.N., Basavaraju, H. 2008. Field Efficacy of Panchagavya on Insect Pests Recorded During the Study in Tectona Grandis 8 International Journal of Research in Agriculture and Forestry V2. I7 Karnataka, J. Agric. Sci., 13, 176 - 179, 2000

Kurl, S. P., and Kumar, A. 2010. Population dynamics of Helicoverpa armigera (Hubner) in relation to meteorological parameters. Journal of Experimental Zoology, India, 13(1), 129-132.

Lal, K., Milati, S.P., Singh, K. and Singh, S.N. 2008. Bio-efficacy of betacyflurothrin, lamdacyhalothrin and imidacloprid against Earias vittella in okra. Annals of Plant Protection Sciences, 16:21-24.

Lange, W.H. and Bronson, L. 1981.Insect pests of tomatoes. Ann. Rev. Entomol.,26: 345-371.

Mahapatra, S.D.; Aswal, J.S. and Mishra, P.N. 2007. Monitoring population dynamics of tomato fruit borer, Helicoverpa armigera Hubner moths through pheromone traps in Uttaranchal Hills. Ind. Jour. Ent. 69(2): 172-173.

Meng, H.L., Chang, G.S., Rens, Z. 1962. Further studies on cotton bollworm, Heliothis armigera, Acta Entomologica Simica11: 82.

Nagaraju N., Venkatesh, Hm., Warburton, H. and Colvin, J. 2002. Farmers' perceptions and practices for managing tomato leaf curl virus disease in southern India International Journal of Pest Management 48(4):333-338 .

Pandey, R.R., Gurang TB, GC-YD, Gurang, G. 1997. Monitoring and management of tomato fruit worm (Helicoverpa armigera) and its egg parasite (Trichogrammaishi) in western hills. Working Paper Lumle Regional
Agricultural Research Center No 97-24 iii: 14 .

Parihar, S.B.S. and Singh, B.R. 1986. Incidence of Heliothis armigera (Hub.). A fruit borer on tomato. Indian J. Plant Prot. 13: 133-136.

Raghupati, G., Chari, M.S. and Rao,S.G. 1995. Relative efficacy of Bacillus thuringiensis formulation against gram pod borer $H$. armigera Hub. on chickpea. Paper presented at National Seminar on IPM in Agriculture held at Nagpur (India) in Dec. 29-30, 25 P.

Rajput, A. A., Sarwar, M., Ahmad, N., Siddiqui, Q. H., and Toufiq, M. 1991. Evaluation for resistance in some local and exotic chickpea genotypes against Helicoverpa armigera (Hubner). Pakistan Journal of Biological Sciences, 6(18), 1612-1615.

Ravi, G, and Verma, S. 1997. Seasonal incidence of chickpea pod borer, Helicoverpa armigera and its larval parasitoid on chickpea crop. Indian $J$ Ent 59 (4): 359-361

Reddy, N.A. and Kumar, C.T.A. 2005. Influence of weather factors on abundance and management of serpentine leaf minor, Liriomyza trifolii (Burgess) on tomato. Ann. Pl. Protec. Sci., 13(2):315-318.

Sajjad M., Ashfaq M., Suhail A. and Akhtar, S. 2011. Screening of tomato genotypes for resistance to tomato fruit borer, Helicoverpa armigera in Pakistan. Pak. J. Agric. Sci. 48, 49-52.

Saradhi, P. M. and N. C. Patnaik, 2004. Seasonal population fluctuation of serpentine leaf miner.

Sarangdevot, S.S., Kumar, S, Naruka PS and Pachauri C.P.. 2010. Population dynamics of whitefly, Bemisia tabaci (Genn.) of tomato in relation to abiotic factors. Pestology, 34(7): 83-84.

Selvraj; Bisht, R.S. 2014. Seasonal incidence of Helicoverpa armigera on tomato at 
Pantnagar, Uttrakhand. International journal of basic and applied agriculture research 12 (3)351-355.

Singh, K., Raju, S. V. S. and Singh, D. K. 2011. Population Succession of tomato fruit borer (Helicoverpa armigera) on tomato (Lycopersicon esculentum Mill.) agro-ecosystem in eastern region of UP. Vegetable Science, 38(2), 152-155.

Singh, H and Singh. G. 1975. Biological studies on Heliothis armigera (Hübner) in Punjab Indian J. Entomol., 34 (1975), pp. 154-164.

Sharma, S.K and Choudhary, J.P. 1997. Effects of different levels of constant temperature and humidity on the development and survival of Heliothis armigera Hub. Indian J Ent 50 (1): 7681.

Tripathi, S and Varma, A. 2002. Identification of sources of resistance in Lycopersicon species to Tomato leaf curl geminivirus (ToLCV) by agroinoculation. Euphytica129: 43-54

Tewari, G.C. and Krishnamoorthy, P.N. 1984. Yield loss in tomato caused by fruit borer. Indian J. Agric. Sci., 54: 341-343.

Wakil, W., M.U. Ghazanfar, Y.J. Kwon, M.A. Qayyum and F. Nasir, 2010.Distribution of Helicoverpa armigera Hübner (Lepidoptera:Noctuidae) in tomato fields and its relationship to weather factors.Entomol. Res., 40: 290-297

Zafar, Khalid., Suhail, Anjum., Arshad, M. and Jalal M.Arif. 2013. Impact of Weather Factors on population fluctuation of $H$. armigera on $H$. armigera on Sunflower. Pakistan Journal of Nutrition 12 (1):50-54, 2013.

\section{How to cite this article:}

Nistha Rawat. 2020. Insect Pest Complex of Tomato Crop and its Population Dynamics and Correlation with Weather Factors. Int.J.Curr.Microbiol.App.Sci. 9(08): 3233-3241. doi: https://doi.org/10.20546/ijcmas.2020.908.369 